\title{
OSALLISTAVA JA TUTKIMUKSELLINEN KEMIAN OPISKELU LUOKANOPETTAJIEN KOULUTUKSESSA
}

\author{
Maija Rukajärvi-Saarela ${ }^{1}$, Kari Kiviniemi ${ }^{2}$ \& Maija Aksela ${ }^{3}$ \\ ${ }^{1}$ Tekniikka ja liiketalous, Kokkola-Pietarsaaren yksikkö, Centria-ammattikorkeakoulu \\ ${ }^{2}$ Kokkolan yliopistokeskus Chydenius, Jyväskylän yliopisto \\ ${ }^{3}$ Kemian opettajankoulutusyksikkö, Kemianlaitos, Helsingin yliopisto
}

Tiivistelmä Luokanopettajat ovat avainasemassa lasten innostuksen herättämisessä sekä kemian tietojen ja taitojen kasvun tukemisessa alakoulussa. Tämän tutkimuksen päätavoitteeksi asetettiin kehittää luokanopettajan perus- ja täydennyskoulutukseen osallistava koulutusmalli, joka tarjoaa sekä sisällöllisiä että menetelmällisiä työkaluja kemian opettamiseen tutkimuksellisuutta korostaen. Opetus- ja opiskelukäytäntöjä kehitettäessä tukeuduttiin kemiaan luonnontieteenä, erityisesti sen kokeellisuuteen ja tutkimuksellisuuteen, sekä osallistavaa ja ammatillista kehittymistä tukevaa opettajankoulutusta käsitteleviin teoreettisiin lähtökohtiin. Koulutusmallia olivat tutkijan ja kouluttajien kanssa yhteisöllisesti kehittämässä yhteensä 168 peruskoulun opettajaa ja luokanopettajaopiskelijaa. Tutkimusaineiston muodostivat kolmen aallon yhteensä seitsemässä mesosyklissä hankitut kysely- ja havainnointiaineistot, opettajaopiskelijoiden kirjoittamat reflektoivat prosessipäiväkirjat ja koulutusmallien kehittämisprosessit sekä kehitetyt koulutusmallit. Aineistojen analysoinnissa käytettiin pääosin laadullisen sisällönanalyysin metodeja mutta mukana on myös määrällisiä osioita. Kehitetyssä koulutusmallissa workshop-tyyppisen koulutuksen sijaan työskennellään autenttisessa oppimisympäristössä, jossa myös oppilaat ovat osa-aikaisesti mukana. Koulutus on osallistavaa ja se tarjoaa innostavan ja turvallisen tavan harjoitella tutkimuksellisuutta ja sen ohjausta. Erityisen merkityksellisiä oppiminen kannalta ovat opettajien koulutuksen aikana saamat omakohtaiset oppimis- ja ohjaamiskokemukset sekä niiden pohdinnat, kouluttajien antama rohkaisu sekä yhteisöllinen tuki. Nämä rohkaisevat opettajia siirtämään tutkimuksellisuutta myös omaan opetukseen. Opettajaopiskelijoiden koulutuksen aikana kirjoittamat reflektoivat prosessipäiväkirjat ja niissä esille nostettujen asioiden lähes reaaliaikainen huomioiminen meneillään olevassa koulutuksessa ja yhteisissä pohdinnoissa tukevat korkeamman tason kognitiivisia prosesseja ja edesauttavat ammatillista kehittymistä. Tutkimustuotteena saatiin myös kuvaus siitä, kuinka tutkimuksellisuutta tukeva oppimisympäristö koulussa tulee järjestää opetukseen sopivaksi esimerkiksi välineistön ja tilojen suhteen. Oppimisympäristön suunnittelussa tulee huomioida myös positiivisen ja sallivan ilmapiirin merkitys oppimiseen.

Avainsanat kehittämis- eli designtutkimus, tutkimuksellisuus, osallistava opettajankoulutus, kemian opetus, alakoulu

\section{Johdanto}

Tänä päivänä nuorten mielenkiinto luonnontieteellisiä ja teknisiä aloja kohtaan on heikkoa ja alan opiskelupaikat jäävät osin jopa täyttämättä niin Suomessa kuin muissakin teollistuneissa maissa. Peruskoulun alaluokat ovat kriittistä aikaa saada lasten innostus heräämään luonnontieteitä kohtaan. Tällöin luodaan luonnontieteiden opetussuunnitelman tavoitteiden mukaisesti niin tiedollinen kuin myös taidollinen perusta luonnontieteiden 
opiskeluun, joten sen on oltava mielenkiintoista ja innostavaa, ja sen on kyettävä herättämään uteliaisuutta ympäröivää maailmaa kohtaan. Alaluokilla opettajina kaikissa aineissa toimivat luokanopettajat. He tarvitsevat työnsä tueksi koulutusta, joka tuottaa suoraan käytäntöön sovellettavissa olevaa osaamista. Erityisesti täydennyskoulutuksen tulisi kohdentua opettajien tietojen ja taitojen päivittämiseen. Kaikki opintokokonaisuudet tai oppiaineet ja niiden opettaminen (esimerkiksi kemia ja fysiikka alakoulussa) eivät välttämättä ole entuudestaan tuttuja kaikille opettajille.

Kemialle, joka on empiirinen luonnontiede, on luonteenomaista erilaisten konkreettisten kokeiden ja tutkimusten tekeminen, joten tutkivan otteen tulisi olla olennainen osa myös kemian opettamista. Alaluokilla kemianopettajana toimii luokanopettaja, joka tarvitsee koulutusta suoriutuakseen tästä haasteelliseksi kokemastaan tehtävästä. Hänen roolinsa lasten asenteiden ja motivaation luojana, kemian oppimisen ohjaajana ja asiantuntijana sekä perustyötapojen, esimerkiksi pipetoinnin, opettajana on erittäin tärkeä. Tutkimuksissa on nimittäin havaittu, että monet taidot ja asenteet, jotka määrittävät myöhemmin oppilaiden suoriutumista, näyttävät kiteytyvän melko muuttumattomiksi jo koulunkäynnin alkuvaiheessa (esim. Kupari, Sulkunen, Vettenranta \& Nissinen 2012, 58). Tutkimuksellisen lähestymistavan mukaisesti järjestetyllä oppilaslähtöisellä opetuksella tutkimusten mukaan on saavutettu positiivisia vaikutuksia oppilaiden motivaatioon luonnontieteiden opiskelua kohtaan (esim. Minner, Levy \& Century 2010). Tutkimuksellisesta näkökulmasta luonnontieteiden opetusta lähestymällä voidaan lisätä myös oppilaiden ymmärrystä tieteen luonteesta ja sen ilmiöistä sekä kehittää heidän luonnontieteellistä ajattelu- ja päättelykykyään (Lavonen \& Laaksonen 2009). Tutkijoiden ja opettajien mielestä tutkimuksellinen opiskelu innostaa oppilaita käyttämään tutkimustaitoja, luomaan merkitysrakenteita ja hankkimaan luonnontieteellistä tietoa (Alake-Tuenter, Biemans, Tobi, Wals, Oosterheert \& Mulder 2012). Toisaalta opettajan näkökulmasta positiivinen mielikuva luonnontieteiden tutkimuksellisesta opetuksesta, oppilaskeskeiset työtavat ja kannustava ilmapiiri ovat edellytyksiä myös suotuisasti kehittyvälle opettajan tutkimuksellisuuden toteuttamiselle koulussa (Leonard, Boakes \& Moore 2009).

\section{Aikaisempaa tutkimustietoa tutkimuksellisuudesta ja täydennyskoulutuksesta}

Kansainvälisiin täydennyskoulutuksiin liittyvissä tutkimuksissa korostuvat aineenhallintaan liittyvät koulutussisällöt. Lisäksi tavoitteena niissä on päästä opettajakeskeisestä ja tiukasti ylhäältäpäin ohjatusta opetuksesta oppilaskeskeiseen ja ilmiöitä käsittelevään oppimiseen. (Whitenack \& Swanson 2013; Darlin-Hammond 2006; Zeichner 2010). Suomalaisten opettajien aineenhallinta on valmistumisen jälkeen korkealla tasolla, joten täydennyskoulutuksissa tulisi meillä enemmän painottaa työelämässä vastaan tulevia sisältöjä, käytänteitä ja haasteita. Erityisesti yhteisöllisyyttä Helinin (2014) tutkimuksen mukaan voidaan pitää tulevaisuuden täydennyskoulutuksen kulmakivenä, kun visiona on työyhteisöjen kehittyminen oppivina organisaatioina. Hänen mukaansa 
täydennyskoulutuksen tärkeimmiksi tavoitteiksi on syytä asettaa yhteistyö, työyhteisön toimivuus ja sitoutuminen.

Tehokas opettaja auttaa opiskelijoita pysymään kiinnostuneina ja kehittämään positiivista asennetta luonnontieteitä kohtaan. Hän pystyy saamaan opiskelijat mukaan tuotoksia aikaansaavaan luonnontieteiden opiskeluun (Schreiner \& Sjöberg 2004). Tutkimuksellisen opiskelun avulla on mahdollista pitää ihmettely ja uteliaisuus elävänä luokkahuoneessa ja sen on todettu tukevan myös korkeamman tason ajattelutaitojen kehittymistä. (Esim. Lavonen, Juuti, Meisalo, Uitto \& Byman s.a.; Aksela 2005; Collins, Osborne, Ratcliffe, Millar \& Duschl 2001.) Tutkimuksellinen opettaminen on myös EU:n suosittelema työtapa opetukseen (Rocard, Csermely, Jorde, Lenzen, Walberg-Henriksson \& Hemmo 2007).

Tässä tutkimuksessa kemian opettajakoulutuksen järjestämisessä lähdetään liikkeelle luonnontieteille tyypillisten kokeellisten työtapojen laajasta hyväksikäytöstä. Uudet käsitteet pyritään sitomaan aiemmin opittuihin käsitteisiin ja kokemuksiin. Kokemuksien kautta käsitteet on tarkoitus sitoa myös oppijoiden jokapäiväiseen elämään. Opetuksessa pyritään monikanavaisuuteen kokeellisuuden ja erilaisten tehtävien avulla. Opettajankoulutuksessa tutkimuksellisen kemian opiskelun tulee olla tarkoin suunniteltua ja mukana on koko ajan oltava kouluttajien tarjoama opetuksellinen tuki. Siten tutkimuksellinen opiskelu on kuin ohjattu tutkimusprosessi, jossa keskeisenä ajatuksena on omien ajatusten, ideoiden ja tulkintojen tuottaminen ja jakaminen yhteistä arviointia ja kehittelyä varten. Tavoitteena on koulutuksen aikana käyttää aikaa yhteisiin pohdintoihin ja reflektointiin niin tuloksista kuin monipuolisemminkin kemiasta ei ainoastaan mitä - vaan myös miten -kysymysten avulla. (Krajcik \& Sutherland 2010; Wandersee \& Baudouin Griffard 2002, 30; Collins ym. 2001, 56; Osborne, Erduran, Simon \& Monk 2001.)

Reflektoinnin tärkeys opettajan ammatillisessa kehittymisessä on tutkimusten mukaan ilmeinen. Wilsonin (2008) tutkimuksen mukaan reflektiota tarvitaan erityisesti, jotta muutokset johtavat kohti elinikäistä oppimista ja kehittymistä. Ferreira, Ryan ja Tilbury (2007) esittävät, että reflektio on ammatillisen kehittymisen kannalta välttämätöntä, sillä sitoutuminen kehittymiseen kasvaa reflektion kautta. Tässä tutkimuksessa kiinnitetään reflktointiin erityisen paljon huomiota, kuten jo edellisessä kappaleessa kerrottiin. Tämän lisäksi koulutettavilla on käytössä reflektoivat prosessipäiväkirjat.

\section{Tutkimuksen päämäärä ja tutkimuskysymykset}

Tämän kehittämis- eli design-tutkimuksen päämäärä oli varsin pragmaattinen: kehittää luokanopettajan perus- ja täydennyskoulutukseen osallistava koulutusmalli, joka tarjoaa sekä sisällöllisiä että menetelmällisiä työkaluja kemian opettamiseen tutkimuksellisuutta korostaen. Käytännössä tavoitteena oli aluksi kahdessa aallossa kehittää alakoulun kemian opettamisen tueksi tarkoitettu täydennyskoulutusmalli, joka perustui aikaisempaan tutkimustietoon, luokanopettajien tarpeisiin sekä noudatti voimassa olevia opetussuunnitelman perusteita (Opetushallitus 2004). Tämän jälkeen kolmannessa aallossa 
kehitettiin luokanopettajien aikuiskoulutuksen käyttöön fysiikan ja kemian kurssimalli edellä kerrotulla tavalla kehitetyn täydennyskoulutusmallin pohjalta. Kuviossa 1 kuvataan tämän kehittämistutkimuksen rakennetta McKenneyn ja Reevesin (2012, 76-78) hahmottaman syklimallin pohjalta.

\section{Kehittämistutkimusaallot}

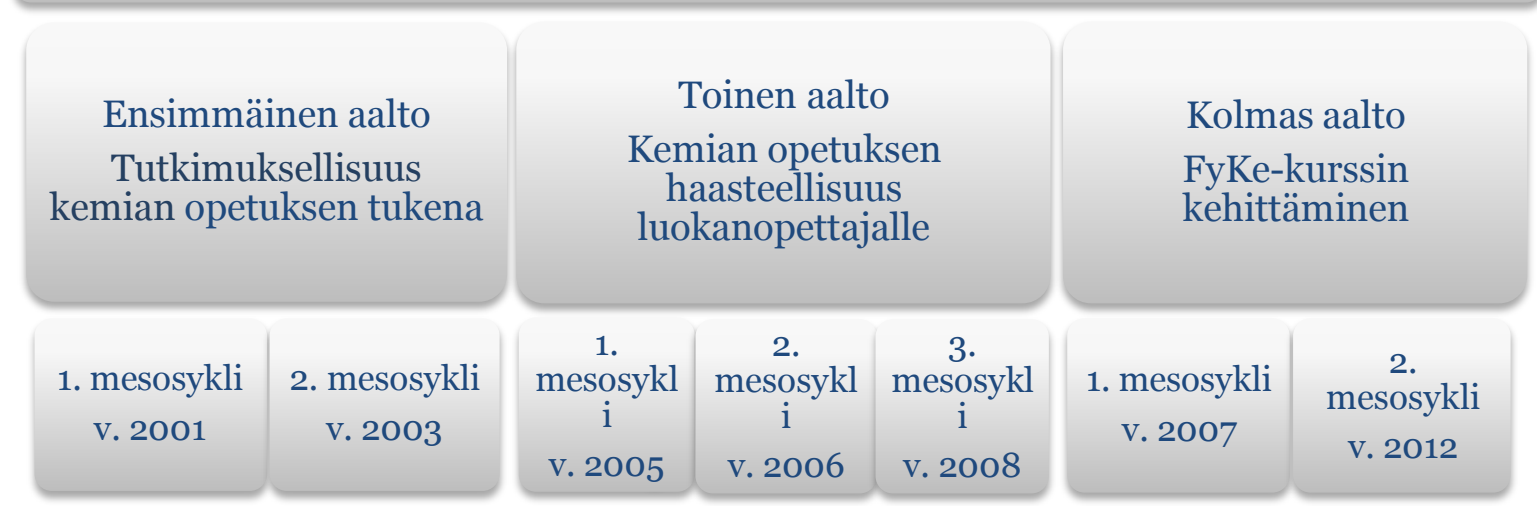

Kuva 1. Kehittämistutkimusaallot mesosykleineen

Kehittämisprosessin aikana asetettuun tavoitteeseen pyrittiin yhteisöllisesti tutkimalla ja kehittämällä kemian tutkimuksellisen opiskelun menetelmää ja tapaa, oppimisympäristöä ja -välineitä sekä niiden kehittämiskäytäntöjä. Toimintaympäristönä kehittämistutkimuksessa olivat luokanopettajan täydennyskoulutus ja aikuiskoulutus autenttisessa oppimisympäristössä, johon kuului myös oppilaiden mukanaolo osa-aikaisesti.

Kehittämistutkimukselle tyypilliseen tapaan tässä tutkimuksessa aineiston keruu ja analysointi olivat monimenetelmäistä, vaikkakin pääosin käytössä olivat laadulliset menetelmät (Wang \& Hannafin 2005). Ohjenuorana tutkimuksessa toimivat kolme päätutkimuskysymystä, jotka käsittelevät kehittämistutkimuksen kolmea ydinosa-aluetta (Edelson 2002; 2006). Kysymykset olivat seuraavat:

- Kehittämisprosessi: Millaisia mahdollisuuksia ja haasteita yhteisöllinen toiminta asettaa luokanopettajan perus- ja täydennyskoulutuksen kehittämiselle?

- Ongelma-analyysi: Millaisia uusia mahdollisuuksia ja haasteita osallisuus ja yhteisöllisyys opettajankoulutuksessa tuovat tutkimuksellisen kemianopetuksen tukemiselle?

- Kehittämistuotos: Millaisia ominaisuuksia on tutkimuksellista kemian opetusta peruskoulun alaluokilla tukevalla, osallistavalla luokanopettajan perus- ja täydennyskoulutuksella?

Kehittämistuotos eli kehittyvä koulutusmalli ja sen jäsentäminen on tutkimuksen tärkein ydinosa-alue, joten sitä koskeva kysymys nousee keskeiseksi. Muut kaksi kysymystä toimivat apuna päämäärään pääsemiseksi. Koulutusmallin kehittämisprosessissa itse koulutusmallin 
suunnittelu ja sen toteutusprosessi tehtyjen tarveanalyysien tuloksia hyödyntäen ovat toki olleet myös tärkeässä roolissa.

Päätutkimuskysymyksiin vastattiin analysoimalla kehittämistutkimuksen kolmen aallon seitsemässä mesosyklissä hankitut (taulukko 1) havainnointi- ja kyselyaineistot (esimerkkinä alkukyselylomakkeesta liite 1 ja arviointikyselylomakkeesta liite 2) ja koulutettavien kirjoittamat prosessipäiväkirjat (kirjoitusohjeistus liiteenä 3), analysoimalla koulutusmallien kehittämisprosessit, ja kehittämällä koulutusmallit sekä perus- että täydennyskoulutukseen. Kehitys- ja tutkimustyöhön osallistui yhteensä 168 peruskoulun opettajaa ja opettajaopiskelijaa tutkijan ja neljän kouluttajan lisäksi. Aineistojen analysoinnissa käytettiin pääosin laadullisen sisällönanalyysin metodeja, mutta mukana on myös määrällisiä osioita.

Taulukko 1. Tutkimusaineiston keruumenetelmät ja ajoitus

\begin{tabular}{|c|c|c|c|c|c|}
\hline \multirow{3}{*}{$\begin{array}{l}\text { Koulutusryhmä } \\
\text { Ajankohta }\end{array}$} & \multicolumn{5}{|c|}{$\begin{array}{c}\text { Aineiston keruumenetelmät } \\
\text { Lukumäärä }\end{array}$} \\
\hline & \multirow{2}{*}{$\begin{array}{l}\text { Havainnoinnit } \\
\text { koulutuksen } \\
\text { aikana }\end{array}$} & $\begin{array}{l}\text { Alkukyselyt } \\
\text { ennen }\end{array}$ & \multicolumn{2}{|c|}{$\begin{array}{c}\text { Loppukyselyt koulutuksen } \\
\text { päätteeksi }\end{array}$} & \multirow{2}{*}{$\begin{array}{l}\text { Koulutuksen } \\
\text { aikana } \\
\text { kirjoitetut } \\
\text { prosessi- } \\
\text { päiväkirjat }\end{array}$} \\
\hline & & laadullinen & laadullinen & määrällinen & \\
\hline \multicolumn{6}{|l|}{$\begin{array}{l}\text { Ensimmäinen } \\
\text { aalto }\end{array}$} \\
\hline v. 2001 & 19 & & 19 & 19 & \\
\hline v. 2003 & 16 & & 16 & 16 & \\
\hline \multicolumn{6}{|l|}{ Toinen aalto } \\
\hline v. 2005 & 24 & 24 & 24 & & \\
\hline v. 2006 & 16 & & & & \\
\hline v. 2008 & 15 & 15 & 15 & & \\
\hline \multicolumn{6}{|l|}{ Kolmas aalto } \\
\hline v. 2007 & 39 & 39 & 39 & & 39 \\
\hline v. 2012 & 39 & 39 & 39 & & 39 \\
\hline
\end{tabular}

Sekä kyselyssä saatu aineisto että prosessipäiväkirjojen muodostama aineisto analysoitiin teoriaohjaavan sisällönanalyysin keinoin käyttäen teemakohtaisia luokituksia ja tyyppivastauksia sekä poikkeavia vastauksia. Johtopäätösten tekoon antoi tietoa myös kurssin aikana kouluttajien tekemät havainnot ja käydyt ryhmäkeskustelut. Esimerkkinä kyselyaineiston analysoinnista esitetään alla oleva ote. Kyseessä on kolmannen aallon 2. syklin kurssille osallistuneiden opettajaopiskelijoiden puolistrukturoitun tutkimuskyselyn (liite 2) vastausten analysoinnista. Saatu aineisto ryhmiteltiin seuraavien pääteemojen mukaan: 1) Tutkimuksellisen opiskelun haasteet ja mahdollisuudet sekä 2) Sisällöt, kehitetyt työtavat ja käytänteet FyKe-kurssilla. Taulukosta 2 selviää, kuinka aineistosta saaduista pelkistetyistä ilmauksista muodostettiin alaluokkia ja ne on viety kyselylomakkeesta saatujen valmiiden yläluokkien alle. 
Taulukko 2. Kolmannen aallon 2. syklin kurssin laadullinen arviointi

\begin{tabular}{ll}
\hline Alaluokka & Yläluokka \\
\hline Opettajan toiminta & \\
Yhteistoiminta opettaja-oppilas & Tutkimuksellisen opiskelun haasteet ja \\
Ilmapiiri & mahdollisuudet \\
Oppijan toiminta & \\
Asennemuutos kemiaa kohtaan & Sisällöt, kehitetyt työtavat ja käytänteet FyKe- \\
Aineenhallinta & kurssilla \\
Oppijan ohjaaminen & \\
Koko ryhmän ohjaus & \\
Oppimisympäristö & \\
Päiväkirja-reflektointi & \\
\hline
\end{tabular}

Seuraavassa tarkastellaan esimerkin omaisesti saatuja tuloksia ensimmäisestä teemaluokasta. Teemaluokan sisältöjä kuvaamaan liitetään mukaan myös suoria lainauksia opettajien antamista vastauksista. Tutkimuksellisen opiskelun ohjaus kurssin aikana oli opettajaopiskelijoiden kokemuksen mukaan tuntunut luontevalta ja hauskalta, vaikkakin haasteellista johtuen puutteellisesta aineenhallinnasta. Aika pian he olivat huomanneet, että oppimistehtävänä olleet käsitteet ja ilmiöt oli syytä selvittää itselle viimeistään ennen kuin niille oli oikeasti käyttöä opetuksessa.

12015k: "Oppilaiden ohjaus oli toisinaan hankalaa omien puutteellisten pohjatietojen takia. Siitä syystä tuntui, että ohjaaminen oli "tahmeaa". Toisaalta itselle tuli ahaa-elämyksiä pienistä asioista ja tunsin oppivani itsekin."

1205k: "Alkuun minua hieman jännitti ohjata oppilaita. Alun jälkeen innostuin koko oppimisprosessista. Opin paljon tehtävistä ja ymmärsin paremmin FyKen asioita.”

Analysointia jatkettiin ja lopuksi tehtiin koko mesosyklin koulutuksesta myös toinen teemaluokka huomioiden koonti ja johtopäätökset seuraaviin toimiin jatkossa.

\section{Tutkimuksen tulokset ja luotettavuustarkastelu}

Kehittämistutkimuksessa ilmiön, tässä tapauksessa tutkimuksellisen ja kokeellisen lähestymistavan tarkastelu kemian opetuksessa, oli kokonaisvaltaista (esim. Edelson 2002). Kuten aiemmin on esitetty, tutkimus koostui kolmena aaltona tehdystä kehittämistutkimuksesta. Käytännöllisenä tavoitteena oli tuottaa motivoiva ja osallistava koulutusmalli, jota voidaan soveltaa kokeelliseen ja tutkimukselliseen kemian opetukseen niin luokanopettajien peruskoulutuksessa kuin myös täydennyskoulutuksessa. Kehittämistutkimukselle luonteenomaisesti tutkimus oli systemaattista ja iteratiivista niin aaltojen sisällä kuin myös niiden välillä. Saavutetut tulokset sisällytettiin aina osaksi tutkimuksen kehittämistä. Tulosten tarkasteluun sisältyvät kehittämistutkimuksen kaikki kolme ydinosa-aluetta eli kehittämisprosessi, ongelma-analyysi ja kehittämistuotos, joiden pohjalta seuraavassa tarkastellaan saatuja tutkimustuloksia. 


\subsection{Kehittäjätahojen yhteisöllisyys koulutusmallin suunnittelussa ja toteutusprosessissa}

Ensimmäisenä vastataan koulutusmallin kehittämisprosessia käsittelevään kysymykseen, kun kehittämistutkimuksessa tavoitteena oli kehittää tutkimuksellisen ja kokeellisen kemian opetukseen soveltuva opettajakoulutuksen toteutusmalli. Kehittämistutkimus tapahtui kolmena aaltona yhteensä seitsemässä syklissä toteutettujen koulutusten yhteyksissä. Niihin on liittynyt jatkuvaa testaamista, arviointia ja kehittämistä, mikä on pyritty dokumentoimaan ja raportoimaan systemaattisesti (vrt. Nieveen \& Folmer 2013). Samoin on raportoitu myös kehittämisprosessin muuttumista tutkimuksen edetessä (vrt. Collins ym. 2004). Tutkija Maija Rukajärvi-Saarela toimi pääkoordinaattorina koko tutkimuksen ajan ja hän edustaa myös sekä luokan- että aineenopettajakategoriaa. Hänen lisäkseen suunnittelija- ja kouluttajatyöryhmässä ensimmäisessä aallossa oli osallisena yksi luokanopettaja, toisessa aallossa yhteensä kolme aineen- ja yksi luokanopettaja ja kolmannessa aallossa sama luokanopettaja kuin ensimmäisessä aallossa. Näin suunnittelijaja kouluttajatyöryhmien toimintaan kehittämistutkimuksessa kuuluu yhteisöllisyys ja kehittämistyössä hyödynnetään jaettua asiantuntijuutta ja osallisten erilaista osaamista (vrt. Nieveen \& Folmer 2013; Nieveen ym. 2006; Design- Based Research Collective 2003; Collins 1992).

Varsinaisen kehittämis- ja kouluttajatyöryhmän rinnalla koulutettavien rooli kehitystyössä kasvoi tutkimuksen edetessä. Ensimmäisessä aallossa heidän roolinsa oli lähinnä tuotoksen arviointi. Toisessa aallossa tuotoksen arvioinnin lisäksi tarveanalyysikyselyn avulla koulutettavilta saatiin arvokasta tietoa suunnittelu- ja kehittämistyöhön. Edellisten toimien lisäksi kolmannessa aallossa luokanopettajaopiskelijaryhmät osallistuivat kehittämiseen myös toiminnan jatkuvalla reflektoinnilla kirjoittamalla prosessipäiväkirjaa, josta lähes reaaliaikaisesti kouluttajat saattoivat huomioida asioita meneillään olevassa koulutuksessa sekä nostaa asioita koko ryhmän pohdittaviksi. Päiväkirjareflektointi ja niissä esille tuotujen asioiden yhdessä pohtiminen sitoutti koulutettavia ja motivoi heitä reflektoimaan asioita yhä syvällisemmin niin opettamisen kuin myös oman oppimisen kannalta. Tällainen yhteisöllisyys ja osallisuus lisää kehittämisen onnistumisen mahdollisuuksia. Samalla se myös haastaa kouluttajatyöryhmää reagoimaan ja toimimaan reaaliaikaisesti. Pernaan (2011) mukaan yhteisöllisyyden myötä innovaation diffuusio on taatumpaa, koska yhteisöllisyys sitouttaa koulutettavat osaksi kehittämisprosessia ja yhteisöä, mikä puolestaan parantaa tuotoksen soveltuvuutta käyttäjien tarpeisiin. Tämä tukee edelleen innovaation käyttöönottoa kemian opetuksessa. Kuitenkin on muistettava, että onnistuessaankin kehittämistutkimuksen siirrettävyys ja tavoitteiden saavuttaminen toteutuu ensisijaisesti paikallisesti (vrt. Barab \& Squire, 2004). 


\subsection{Kehitettyjen koulutusmallien mahdollisuudet ja haasteet tutkimuksellisen ja kokeellisen kemian opetuksen tukemiseen}

Toisessa ydinosa-alueessa keskitytään ongelma-analyysiin, jossa tavoitteena oli löytää mahdollisuuksia ja haasteita, joita osallistava opettajakoulutus tuo tullessaan peruskoulun alaluokkien tutkimukselliseen kemian koulutukseen.

Tutkimuksellisuus ja kokeellisuus alakoulujen kemian opetuksessa tarjoaa mahdollisuuksia käyttää aktivoivia ja oppilaskeskeisiä työtapoja kemian opiskelussa alakoulussa (esim. Whitenack \& Swanson 2013; Zeichner, 2010; Darlin-Hammond, 2006). Tästä oltiin kehittämistutkimuksen kaikissa kolmessa aallossa tehtyjen tutkimusten mukaan yhtä mieltä. Esimerkiksi ensimmäisessä aallossa toteutettu tutkimuksellisuus innosti opettajia pohtimaan omaa käytössä olevaa kemian pedagogiikkaa ja miettimään erityisesti haastetta saada oman luokan oppilaat uteliaina ja innostuneina tutkimaan kemian ilmiöitä ja tekemään kokeita.

Kun oma innostus muuttaa opetusmenetelmiä kohti oppilaskeskeisyyttä ja tutkimuksellisuutta oli herännyt, oli tutkimuksen mukaan opettajien mielestä tärkeää saada myös kollegat omalla koululla mukaan toimintaan. Helinin (2014) ja Wilsonin (2008) mukaan yhteisöllisyys ja sen sisällä yhteistyö, työyhteisö ja sitoutuminen edesauttavat asioiden toteutumisen kouluyhteisössä, ja tapahtuu innovaation diffuusiota. Toisen aallon kolmannessa syklissä esimerkiksi valittiin tietoisesti täydennyskoulutukseen osallistujat niin, että kultakin koululta tuli koulutukseen työpari, jotta he pystyivät koulutuspäivien välilläkin pohtimaan asioita keskenään oman koulun näkökulmasta.

Tutkimuksellisuus ja kokeellisuus opiskelussa vaativat toisenlaista suhdetta opettajan ja oppijan välille kuin tavanomaiset opetustavat. Ne vaativat esimerkiksi korkeamman tason organisointia, suunnittelua ja jäsentelyä niin opettajalta kuin oppilailtakin (vrt. Barnett \& Hodson 2001). Toisen aallon ensimmäisessä syklissä tutkimuksen keskiössä oli erityisesti opettajan rooli, jonka havaittiin olevan moninaisen ja vaativan. Havaittiin, että jo opetuksen suunnitteluvaiheessa opettajan on kiinnitettävä huomiota opetettavan asiasisällön lisäksi oppimisympäristön luomiseen ja varustamiseen oppilaita stimuloivaksi. Mielenkiintoisen oppimisympäristön huomattiin tukevan oppilaiden kiinnostusta luonnontieteiden opiskelua kohtaan (vrt. Fitzgerald 2012; Tytler ym. 2008, viii; Havu-Nuutinen, Kauppinen \& Timonen 2005; Aho, Havu-Nuutinen \& Järvinen 2003).

\subsection{Osallistavan ja tutkimuksellisen kemian opetuksen koulutusmalli luokanopettajien perus- ja täydennyskoulutukseen}

Tässä luvussa esittelen kolmessa aallossa tehtyjen tutkimusten tuloksena kehitetyn, tutkimuksellista kemian opiskelua tukevan ja siihen innostavan, osallistavan opettajankoulutusmallin.

Kehitetyssä koulutusmallissa koulutusten aikana opettajia osallistetaan ja heidän uteliaisuutta ja motivaatiota tuetaan esimerkiksi ottamalla käyttöön oppijakeskeisiä ja 
yhdessä tekemiseen keskittyviä työtapoja. Luennoinnin sijaan suositaan pienryhmätyöskentelyä, joissa käytännön kokeiden ja tutkimusten tekemisen lisäksi on mukana ongelmanratkaisua. Näin tutkimuksellisuus käytännön tasolla todella sisältää sekä aktiivista ja fyysistä tekemistä että ajattelua ja järkeilyä, kuten useiden muidenkin tutkimusten mukaisesti tapahtuu (Abrahams \& Reiss 2012; Dietz \& Davis 2009; Howes, Lim \& Compos 2009; Akerson \& Hanuscin 2007; Nakhleh, Polles \& Malina 2002; Millar, Tiberghien \& Le Maréchal 2002).

Opettajankoulutusmallissa kiinnitetään huomiota kannustavan ilmapiirin luomiseen, koska se on tutkimuksellisen opiskelun kontekstissa erittäin merkityksellistä opettajien ja opettajaopiskelijoiden kemiaan ja sen tutkimukselliseen opiskeluun innostumisen kannalta. Vastaavasti Leonard ja kumppanit (2009) ovat tutkimuksessaan todenneet, että opettaja tarvitsee positiivista mielikuvaa luonnontieteiden tutkimuksellisesta opetuksesta, oppijakeskeisiä työtapoja ja kannustavaa ilmapiiriä opettajakoulutuksessa, jotta hän siirtäisi tutkimuksellisuutta koulutuksesta opetukseensa.

Koulutustapahtumassa on hyvä olla samanaikaisesti paikalla useampia toimivia kouluttajia, jotta oppijoille välittyy aitouden tuntu yhdessä pohtimisesta ja tekemisestä, ja heille tarjoutuu mahdollisuus helposti kääntyä tarvittaessa kouluttajan puoleen. Kouluttajien toimintaa seuratessaan koulutettavat saavat kokemusta opettajan toiminnasta elävänä esimerkkinä: koulutustilanteessa kouluttajien innostuneisuus ja käytännön kokemus tutkimuksellisesta lähestymistavasta opetustyössä sekä välitön, ihmistä ymmärtävä ilmapiiri ja keskusteleva ohjaustapa ovat opettajille merkityksellisiä asioita. Tätä tukee myös Schreinerin ja Sjöbergin (2004) tutkimustulokset, joiden mukaan oppijoiden positiivinen asenne luonnontieteitä kohtaan lähtee opettajan tavasta opettaa ja ohjata. Ja opettajat ovat avainroolissa myös tutkimuksellisen lähestymistavan käyttöönotossa omassa työssään (ks. Pernaa 2011).

Koulutusten pitopaikkana autenttinen kemian laboratorio tai vaihtoehtoisesti kemian aineluokka on tietoinen valinta. Tätä tukevat monet aiemminkin tehdyt tutkimukset (esim. Fitzgerald 2012; Tytler ym. 2008, viii; Havu-Nuutinen ym 2005; Aho ym.2003; Aksela \& Juvonen 1999, 15, 19-21). Koulutuksen aikana opettajilla on tällöin mahdollisuus tutustua samalla kemian laitteisiin ja välineisiin laajemminkin, mikä tutkimusten mukaan myös stimuloi heitä yhdessä pohtimaan ja muodostamaan käsitystä alaluokkien luonnontieteiden opiskeluun houkuttelevasta oppimisympäristöstä. Tutkimuksellisessa kemian opiskelussa tarvittavien materiaalien ja välineiden osalta tehtiin koulutukseen osallistuneiden opettajien kanssa kehittämistyötä koko kehittämistutkimuksen ajan. Lopputuloksena oli FyKetarvikelaatikko sisältöineen, jota on kokeiltu muutamilla kouluilla menestyksellisesti.

Koulutuksen aikana tutkittavat ilmiöt ja opiskeltavat käsitteet sekä havaintojen tekeminen on hyvä kytkeä oppijoiden elämisympäristöön ja arkeen, koska tämä saa oppijat innostumaan ilmiöiden ihmettelystä ja sitä myöten aktiivisesta tutkimisesta ja oppimisesta.

Koulutuksen ohjelmaan valittujen tutkimusten ja laborointien on hyvä olla monipuolisia niin aihepiirien kuin myös tehtävien avoimuuden suhteen, ja aihekokonaisuuksien tulee 
kytkeytyä arkipäivään ja olla käytännönläheisiä (vrt. Kärnä ym. 2012; Aksela 2009; Kauppila 2007; Aksela 2005; Opetushallitus 2004; Puolimatka 2002: 41-44; Hakkarainen ym. 1999: 11-13; Domin 1999).

Opettajien kemian sisältötiedon ja aineenhallinnan kehittyminen on myös yksi tärkeä tavoite niin opettajan täydennys- kuin peruskoulutuksessa (vrt. Lucero ym. 2013; Whitenack \& Swanson 2013; Lee 2011; Zeichner, 2010; Tytler ym. 2008; Darlin-Hammond 2006; Luera \& Otto 2005). Tässä koulutusmallissa täydennyskoulutuksessa luokanopettajien aineenhallintaa tuodaan koulutukseen korostamalla kemian käsitteiden ja ilmiöiden opiskelua osana käytännön tutkimusten tekemistä. Luokanopettajan peruskoulutuksessa aineenhallintaa opettajaopiskelijat lisäävät ilmiöiden ja käsitteiden "teoriasta käytäntöön” haltuunottotapaa käyttäen, eli tutkimuksellisen kemian opiskelun kontekstissa kouluttajien ohjaamana opettajaopiskelijat omana etukäteistyötä tutustuvat ilmiöihin ja käsitteisiin, jotka tietoisesti sidotaan käytännössä tehtäviin tutkimuksiin ja laborointeihin.

Koulutettavien opettajien aktiivisella mukanaololla sekä suunnitteluvaiheessa että koulutuksen arvioinnissa varsinaisen toiminnan lisäksi kasvatetaan osallisuutta. Toiminnanaikainen pienryhmätyöskentely puolestaan mahdollistaa aktiivisen reflektoinnin ja toiminnan jatkuvan arvioinnin yhteisöllisesti. (Esim. Lavonen ym. 2006; Prenzel \& Ostermeier 2006; van Driel ym. 2001.) Haasteita, omatoimisuutta ja muutoksia työrooleissa ja -tehtävissä sisältävä yhteistoiminta ja ryhmässä eri tehtävien parissa oppiminen koulutuksen aikana panee oppijoiden omat uskomukset ja totutut käytänteet koetukselle. Tämä vie eteenpäin ammatillisen kehittymisen tiellä (ks. esim. Falk \& Drayton 2009; Sandholz 2002).

Kokemusten reflektointi ja reflektoivan päiväkirjan kirjoittaminen koulutuksen aikana tuo näkyväksi omaa oppimista ja kehittymistä sekä selkiinnyttää ja jäsentää asioita, omia ajatuksia ja oppimista. Tutkimusten mukaan tämä mahdollistaa ammatillista kehittymistä (vrt. Wilson 2008; Ferreira ym. 2007). Kuitenkin reflektoivan prosessipäiväkirjan kirjoittamisen funktio ei välttämättä ole itsestään selvyys. Siksi sen tavoitteellisuus koulutuksessa on syytä selkiinnyttää yhteisissä keskusteluissa; tarvittaessa voidaan määritellä yhdessä esimerkiksi neljä näkökulmaa eli punaista lankaa (liite 3), joita oppijat voivat kuljettaa mukana päiväkirjapohdinnoissaan kurssin ajan ja reflektoida ajatuksiaan niiden pohjalta. Tutkimus osoitti tämän auttavan oppijoita pääsemään reflektoinnissa seuraavalle tasolle ammatillisen kasvunsa pohdinnoissa.

Kehitetyssä koulutusmallissa tutkimuksellisuus ja sekä luokanopettajien että opettajaopiskelijoiden haasteelliseksi kokema oppilaiden ohjaaminen erityisesti avoimien tutkimusten tekemisessä tulee harjoiteltavaksi siten, että käytännössä osa-aikaisesti työskentely tapahtuu pienryhmissä, joissa kussakin on kaksi opettajaa/opettajaopiskelijaa ja kaksi oppilasta. Tällainen tilanne tarjoaa opettajille kouluttajien ohjauksessa turvallisen mahdollisuuden saada kokemusta siitä, kuinka tutkimuksellista opiskelua on mahdollista ohjata eteenpäin oppilaiden kanssa ilmiöitä tutkien ja selittäen, asioita yhdessä pohtien, sopivia kysymyksiä esittäen ja välillä tietoa jakaen ja käsitteitä selkiinnyttäen, kuten Ash 
(2000a), Ash ja Kluger-Bell (2000) sekä Bransford (2000) kumppaneidensa kanssa ovat tutkimuksissaan opettajan roolia tutkimuksellisessa lähestymistavassa kuvanneet.

Kouluttajien vetämät alkumotivoinnit ja loppukoonnit, joissa varmennetaan niin saatuja tutkimustuloksia kuin myös käsitteitä ja ilmiöitä, kuuluvat tärkeänä osana koulutukseen. Sandholtzin (2002) tutkimuksen mukaan ammatillisen kehittymisen tulisikin olla konstruktiivista työskentelyä yhdessä toisten kanssa; toisilta opittaessa tapahtuu kehittymistä.

\subsection{Luotettavuustarkastelua}

Tässä tutkimuksessa kehittämistutkimuksen luotettavuutta tarkastellaan prosessivaliditeetin, käytännöllisen validiteetin ja yleistettävyyden näkökulmista (mm. Kiviniemi 2015). Koska kehittämistutkimuksessa tutkimuksessa lähtökohtana on kehitellä kasvatuksen käytäntöjä palvelevia toimintamalleja ja suunnitteluperiaatteita vaiheittain (Anderson \& Schattuck 2012), luotettavuutta on perusteltua tarkastella monivaiheisen kehittämisprosessin hallinnan kannalta (prosessivaliditeetti). Tämä kehittämistutkimus toteutettiin seitsemässä eri syklissä ja niihin on liittynyt jatkuva testaaminen, arviointi ja kehittäminen, mikä on pyritty myös dokumentoimaan ja raportoimaan systemaattisesti (vrt. Nieveen \& Folmer 2013). Samalla on raportoitu myös siitä, miten kehittämisprosessi on muuttunut tutkimuksen edetessä (vrt. Collins ym. 2004). Kehitettävässä koulutusmallissa oppijalähtöiset ja tutkimukselliset työtavat ovat esimerkiksi olleet suunnittelun keskiössä kaikissa vaiheissa, mutta erilaisten pienryhmien työstämiseen ja opettajan rooliin liittyvät kehittämispyrkimykset ovat jäsentyneet prosessin kuluessa. Kehittämisprosessin hallintaan liittyy myös työskentelyn perustuminen jaettuun asiantuntijuuteen ja osallisten erilaisen osaamisen hyödyntämiseen (Collins 1992; Design-Based Research Collective 2003; Nieveen ym. 2006; Nieveen \& Folmer 2013). Tässä tutkimuksessa tutkimusprosessin alkuvaiheessa vastuullisten koulutuksen suunnittelijoiden ja kouluttajien lisäksi ei osattu täysin hyödyntää koulutukseen osallistuneiden opettajien ja opettajaopiskelijoiden panosta koulutuksen ja sen kehittämismallin suunnittelussa, vaikka heiltä koulutuspalautetta kerättiinkin. Kehittämisprosessin edetessä opettajia ja opettajaopiskelijoita kyettiin tietoisemmin osallistamaan myös toimintamallin kehittämiseen muiden koulutusmallin kehittäjien rinnalla.

Käytännöllisellä validiteetilla viitataan tässä artikkelissa siihen, kuinka kehittämistutkimuksen arvioinnin tulisi kohdentua mm. siihen, miten relevantti alustava ja koko ajan täydentyvä suunnitelma käytännön näkökulmasta on, ja miten hyödylliseksi ja vaikuttavaksi suunnitelma ja kehitettävä toimintamalli arvioidaan opetus- ja oppimiskäytäntöjen kehittämisen näkökulmasta (Nieveen \& Folmer 2013). Tässä tutkimuksessa tämänkaltainen praktinen näkökulma on pyritty ottamaan huomioon tekemällä kehittämistutkimukselle tyypillisesti (Edelson 2006; Plomp 2013) kussakin vaiheessa ongelma-analyysi, minkä suuntaisesti kehittämistyötä on eri vaiheissa tehty ja myös palautetietoa asetettujen tavoitteiden toteutumisesta on kerätty. 
Kehittämistutkimuksessa yleistämisen osalta nousee esille kysymys siitä, miten tavallisesti tiettyyn yksittäiseen kontekstiin liittyvän kehittämistutkimuksen tuloksia on mahdollista yleistää muihin yhteyksiin tai muuhun teoriaan (Edelson 2006; Plomp 2013; McKenney \& Reeves 2014). On mm. esitetty analyyttisen yleistämisen ajatuksen soveltamista kehittämistutkimukseen, missä yhteydessä on viitattu (Plomp 2013; McKenney \& Reeves 2014) mm. tapaustutkimuksen metodiasiantuntijan Yinin näkemyksiin. Yinin $(2003,37)$ analyyttistä yleistämistä koskevan ajattelun keskiössä on saatujen tulosten koettelu useissa erilaisissa konteksteissa. Vastaavaan tapaan myös design-tutkimuksen pioneerien Collinsin (1992) ja Brownin (1992) näkemyksiin on kuulunut laadittujen suunnitteluperiaatteiden kehittely ja testaaminen useissa, luonteeltaan vaihtelevissa konteksteissa, millä on osaltaan pyritty varmentamaan toimintamallien ja kehiteltyjen suunnitteluperiaatteiden toimivuutta. Tämän kaltaisen ajatuksen näkökulmien koettelusta voi katsoa todentuvan jossain määrin myös tässä tutkimuksessa, sillä koulutusmallia on kehitetty useissa eri koulutusryhmissä niin luokanopettajakoulutuksessa kuin opettajien täydennyskoulutuksessakin. Toisaalta tässä artikkelissa esitetty toimintamalli on luonteeltaan suuntaa-antava, jolloin toimintamallin mahdollisten soveltajien tulee pohtia toimintamallia suhteessa omiin sovelluskonteksteihinsa (Reeves 2006; Plomp 2013). Tältä osin sitoudutaan ns. siirrettävyyden (transferability) käsitteeseen (Lincoln \& Guba 1985, 296-298). Tässä artikkelissa siirrettävyyteen liittyvän periaatteen mukaisesti on pyritty esittämään riittävän tarkka kuvaus kehitystyön kontekstista ja periaatteista. Koulutusmallin ja siihen liittyneiden suunnittelukäytäntöjen soveltajien tulee puolestaan pohtia toimintamallia suhteessa omiin sovelluskonteksteihinsa.

\subsection{Pohdintaa tutkimuksen tuloksista ja merkityksestä}

Kehittämistutkimuksen tuloksena syntynyt koulutusmalli, jota on kuvattu luvussa 4.3, kehittyi suuntaan, jossa tutkimuksellisuus vietiin käytäntöön, ja koulutettavat ovat aktiivisia toiminnan osallisia autenttisessa oppimisympäristössä. Toiminnan keskiössä on tällöin tutkimuksellisuus ja sen harjoittelu oppijakeskeisten työtapojen ja pienryhmään perustuvan työskentelyn avulla yhdessä oppilaiden kanssa. Koulutuksessa opettaja joutuu miettimään omaa opettajan ja ohjaajan rooliaan suhteessa oppilaiden ohjaukseen. Keskeisessä roolissa on myös koulutettavien oma reflektointi, mutta toisaalta myös yhteisöllisyys ja yhteiset pohdinnat korostuvat. Näin järjestetyssä koulutuksessa aineenhallintataitojen hankinta sitoutuu luontevasti osaksi käytännön toimintaa, kun oppijoiden elämisympäristöön ja arkeen kytketyt tutkittavat ilmiöt ja opiskeltavat käsitteet sekä havaintojen tekeminen on liitetty osaksi tutkimusten ja laborointien tekoa.

Kemian opetuksen ja opiskelun tutkiminen sekä kehittäminen ovat edelleen erittäin ajankohtainen ja tärkeä aihe myös Suomessa. Jotta meillä olisi tulevaisuudessakin kemiasta innostuneita osaajia, on kemian opiskelu voitava aloittaa asiansa osaavien ja motivoituneiden luokanopettajien opastuksella. Siksi on erittäin tärkeää järjestää luokanopettajille kemian täydennyskoulutusta ja luokanopettajakoulutuksessa fysiikan ja 
kemian kurssi niin, että heille heräisi innostus päästä toteuttamaan koulutuksessa merkitykselliseksi kokemaansa käytännössä. On havaittu, että on haastavaa herättää ja ylläpitää lasten sekä nuorten mielenkiintoa ja motivoida heitä näkemään luonnontieteiden ja tekniikan alat mielenkiintoisina ja houkuttelevina. Tässä tarvitaan luokanopettajia, joilla on tietotaitoa ja kokemusta, mutta ennen kaikkea uskallusta ja innostusta toteuttaa luonnontieteiden opetusta tutkimuksellisesti ja liittämällä sitä lasten elämismaailman.

Suomalainen luokanopettajakoulutus on laadukasta, mutta koulutuksen kehittämisen tarvetta se ei poista. Muutos on jatkuvaa. Kun tavoitteena on tulevaisuuden opettaja, joka pystyy opettamaan oppimisen taitoja ja yhteisöllisiä ongelmanratkaisutaitoja sekä valmiuksia soveltaa ja käyttää opittua käytännössä, ovat tutkimuksellisuus ja yhteisöllinen tiedonrakentaminen osallistavia ja innostavia työskentelymenetelmiä. Niiden käyttöönotto opettajankoulutuksessa tarvitsee lisää tutkimusta. Elinikäinen oppiminen sekä itsensä jatkuvan kehittämisen ja kouluttamisen tärkeys tulee tuoda esille opettajankoulutuksessa. Koulutuksen tulee osallistaa ja haastaa, jotta se antaa innostusta tulevaan työhön.

Kouluilta vaaditaan laaja-alaista, oppiainerajat ylittävää ilmiökeskeistä opetusta sekä yhdessä oppimisen ja vuorovaikutustaitojen harjoittelemista. Tulevaisuuden koulu tarvitsee selkeän, laajan pedagogisen pohjan, joka pitää sisällään ymmärryksen oppimisesta ja oppijoista laaja-alaisesti, sillä oppiminen ei ole suoraviivaista. Tutkimusta tarvitaan, millaisin pedagogisin menetelmin voidaan niin opettajaopiskelijoita kuin myös luokanopettajia tukea omaksumaan tulevaisuuden opetustaitoja.

Muutoksen hallintaan ei pysty yksittäinen opettaja, vaan siihen tarvitaan koko koulu. Täydennyskoulutus Suomessa tällä hetkellä tarvitsee uudistumista. Osallistava koulutus sitouttaa, pelkkä luennointi ei kanna kauas. Koko koulun on kuljettava yhteen suuntaan. Jotta tulevaisuudessa tutkimuksellisuus on tärkeä osa opetusta alakoulusta lähtien, tarvitaan selkeästi osallistavaa opettajankoulutusta.

\section{Lähteet}

Abrahams, I. \& Reiss, M. 2012. Practical work: Its effectiveness in primary and secondary schools in England. Journal of Research in Science Teaching 49 (8), 1035-1055.

Aho, L., Havu-Nuutinen, S. \& Järvinen, H. 2003. Opetus, opiskelu ja oppiminen ympäristö- ja luonnontiedossa. Helsinki: WSOY.

Akerson, V.L. \& Hanuscin, D.L. 2007. Teaching the nature of science through inquiry. Results of a three-year professional development program. Journal of Research in Science Teaching 44 (5), 653-680.

Aksela, M. 2009. Matematiikan ja luonnontieteiden oppimista ja ajattelun taitoa tutkimassa. Raportissa K. Merenluoto \& T.-R. Hurme (toim.) Matematiikan ja luonnontieteiden opetuksen tutkimusseura ry:n tutkimuspäiviltä 28.9.-29.9.2007. Turun yliopiston kasvatustieteiden tiedekunnan julkaisuja. B . Turku: Turun opettajankoulutuslaitos, 9-27.

Aksela, M. 2005. Supporting Meaningful Chemistry Learning and Higher-order Thinking through Computer-Assisted Inquiry: A Design Research Approach. Helsinki: Yliopistopaino. Saatavissa: http://ethesis.helsinki.fi/ julkaisut/mat/kemia/vk/aksela/. Luettu 21.3.2009.

Aksela, M. \& Juvonen, R. 1999. Kemian opetus tänään. Moniste 27/1999. Helsinki: Opetushallitus. 
Anderson, T. \& Shattuck, J. 2012. Design-based research: A decade of progress in education research? Educational researcher 41 (1), 16-25.

Ash, D. 2000. The process skills of inquiry [Monograph]. Foundations 2, 51-62. Saatavissa: http://www.nsf.gov/pubs/2000/nsf99148/ pdf/nsf99148.pdf . Luettu 20.2.2010.

Ash, D. \& Kluger-Bell, B. 200o. Identifying Inquiry in the K-5 Classroom [Monograph]. Foundations 2, 79-86. Saatavissa: http://www.nsf.gov/ pubs/2000/ nsf99148/pdf/nsf99148.pdf .Luettu 10.03.2010.

Barab, S. \& Squire, K. 2004. Design-based research: Putting a stake in the ground. The Journal of the Learning Sciences 13 (1), 1-14.

Barnett, J. \& Hodson, D. 2001. Pedagogical Context Knowledge: Toward a Fuller Understanding of What Good Science Teachers Know. Science Education 85 (4), 426-453.

Brown, A. 1992. Design experiments: theoretical and methodological challenges in creating complex interventions in classroom settings. The Journal of the Learning Sciences 11 (1), 105-121.

Collins, A. 1992. Toward a design science of education. Teoksessa E. Scanlon \& T. O'Shea (toim.) New directions in educational technology. Berlin: Springer, 15-22.

Collins, S., Osborne, J., Ratcliffe, M., Millar, R. \& Duschl, R. 2001. What 'ideas-about-science' should be taught in school science? A Delphi study of the expert community. Saatavissa: http://www.tlrp.org/dspace/retrieve/790/NARST2001_P3.pdf . Luettu 7.9.2011.

Collins, A., Joseph, D. \& Bielaczyc, K. 2004. Design research: Theoretical and methodological issues. The Journal of Learning Sciences 13 (1), 15-42.

Design-Based Research Collective, 2003. Design-based research: An Emerging paradigm for educational inquiry. Educational Researcher 32 (1), 5-8.

Domin, D. 1999. A Review of Laboratory Instruction Styles. Journal of Chemical Education 76 (4), 543-547.

Edelson, D. C. 2002. Design research: What we learn when we engage in design. The Journal of the Learning Sciences 11 (1), 105-121.

Edelson, D. C. 2006. What we learn when we engage in design: Implications for assessing design research. Teoksessa J. van der Akker, K. Gravemeijer, S. McKenney \& N. Nieveen (toim.) Educational Design Research. Abigdon: Routledge, 105-121.

Falk, J. \& Drayton, B. 2009. MSPnet: Design dimensions for nested learning communities. Teoksessa J. Falk \& B. Drayton (toim.) Creating and sustaining online professional learning communities. New York: Teachers College Press, 20-35.

Ferreira, J., Ryan L., \& Tilbury D. 2007. Mainstreaming education for sustainable development in initial teacher education in Australia: a review of existing professional development models. Journal of Education for Teaching 33 (2), 225-239.

Fitzgerald, A. 2012. Science in primary schools: examining the practices of effective teachers: Examining the practices of effective primary science teachers. Rotterdam: Sense Publishers.

Hakkarainen, K., Lonka, K. \& Lipponen, L. 1999. Tutkiva oppiminen. Älykkään toiminnan rajat ja niiden ylittäminen. Helsinki: WSOY.

Havu-Nuutinen, S., Kauppinen, E. \& Timonen M. 2005. Alkuopettajat ympäristö- ja luonnontiedon oppikirjan käyttäjinä. Teoksessa A-L. Huttunen \& A- M. Kokkonen (toim.) Koulutuksen kulttuurit ja hyvinvoinnin politiikat. Kasvatustieteen päivät 2005. Verkkojulkaisu. Jyväskylä: Suomen kasvatustieteellinen seura, 94-104. Saatavissa: http://ebooks jyu.fi /isbn95 I 3923843.pdf . Luettu 21.11.2014.

Helin, M. 2014. Opettajien ammatillisen kehittymisen jatkumo: - yliopiston ja koulujen kumppanuus. Helsingin yliopisto. Käyttäytymistieteellinen tiedekunta, opettajankoulutuslaitos. Väitöskirja. Saatavissa: https://helda. helsinki.fi/handle/10138/44828 . Luettu 22.9.2014.

Howes, E.V., Lim, M. \& Campos, J. 2009. Journeys into inquiry-based elementary science: literacy practices, questioning, and empirical study. Science Education 93 (2) (2009), 189-217.

Kauppila, R. A. 2007. Ihmisen tapa oppia. Johdatus sosiokonstruktivistiseen oppimiskäsitykseen. Jyväskylä: PS-kustannus. 
Kiviniemi, K. 2015. Design- eli suunnittelututkimus opetus- ja kasvatusalalla. Teoksessa R. Valli \& J. Aaltola (toim.) Ikkunoita tutkimusmetodeihin I. Metodin valinta ja aineistonkeruu: virikkeitä aloitteleville tutkijoille. 4. uudistettu ja täydennetty painos. Jyväskylä: PS-kustannus, 220-240.

Kupari, P., Sulkunen, S., Vettenranta, J. \& Nissinen, K. 2012a. Enemmän iloa oppimiseen. Neljännen luokan oppilaiden lukutaito sekä matematiikan ja luonnontieteiden osaaminen: kansainvälinen PIRLS- ja TIMSS-tutkimus Suomessa. Jyväskylän yliopisto, Koulutuksen tutkimuslaitos. Jyväskylä: Jyväskylän yliopistopaino.

Kärnä P., Hakonen R. \& Kuusela J. 2012. Luonnontieteiden osaaminen perusopetuksen 9. luokalla 2011. Teoksessa P. Kärnä, L. Houtsonen \& T. Tähkä (toim.) Luonnontieteiden opetuksen kehittämishaasteita 2012. Koulutuksen seurantaraportit 2012: 10. Tampere: Juvenes Print Suomen Yliopistopaino.

Lavonen, J., Juuti, K., Meisalo, V., Uitto, A. \& Byman, R. s.a. Luonnontieteiden opetuksen kiinnostavuus peruskoulussa. Helsingin yliopisto. Soveltavan kasvatustieteen laitos. Saatavissa: http://mirror4u.net/opettajat/Mirror6_luonnontiet.pdf . Luettu 8.7.2007.

Lavonen, J., Juuti, K., Aksela, M. \& Meisalo, V. 2006. A Professional development project for improving the use of information and communication technologies in science teaching. Technology, Pedagogy and Education 15(2), 159-174.

Lavonen, J. \& Laaksonen, S. 2009. Context of teaching and learning school science in Finland: Reflections on PISA 2006 results. Journal of Research in Science Teaching 46 (8), 922-944.

Leonard, J., Boakes, N. \& Moore, C.M. 2009. Conducting Science Inquiry in Primary Classrooms: Case Studies of Two Preservice Teachers' Inquiry-Based Practices. Journal of Elementary Science Education 21 (1), 27-50. Saatavissa: http://files.eric.ed.gov/fulltext/EJ849709.pdf . Luettu 19.6.2014.

Lincoln, Y.S. \& Guba, E.G. 1985. Naturalistic inquiry. Newbury Park: SAGE.

Lucero, M., Valcke, M. \& Schellens, T. 2013. Teachers' Beliefs and Self-Reported Use of Inquiry in Science Education in Public Primary Schools. International Journal of Science Education 35 (8), 1407-1423.

Luera, G.R. \& Otto, C.A. 2005. Development and evaluation of an inquiry-based elementary science teacher education program reflecting current reform movements. Journal of Science Teacher Education 16 (3), 241-258.

McKenney, S. \& Reeves, T. C. 2014. Educational design research. Teoksessa J. M. Spector, M. D. Merrill, J. Elen \& M. J. Bishop (toim.) Handbook of Research on Educational Communications and Technology. 4 p. New York: Springer, 131-140.

McKenney, S., \& Reeves, T. C. 2012. Conducting Educational Design Research. London : Routledge.

Millar, R., Tiberghien, A., \& Le Maréchal, J-F. 2002. Varieties of labwork. A way of profiling labwork tasks. Teoksessa D. Psillos, \& H. Niedderer (toim.) Teaching and Learning in the Science Laboratory. Dodrecht: Kluwer Academic Publishers.

Minner, D., Levy, A. \& Century, J. 2010. Inquiry-based science instruction - what is it and does it matter? Journal of Research in Science Teaching 47 (4), 474-496.

Nakhleh, M. B., Polles, J. \& Malina, E. 2002. Learning chemistry in a laboratory environment. Teoksessa J. K. Gilbert, O. D. Jong, R. Justi, D. F. Treagust \& J. H. van Driel (toim.) Chemical Education. Towards Research-based Practice. Dordrecht: Kluwer Academic Publishers, 69-94.

Nieveen, N., McKenney, S. \& van den Akker, J. 2006. Educational design research: the value of variety. Teoksessa J. van den Akker, K. Gravemeijer, S. McKenney \& N. Nieveen (toim.) Educational design research. New York: Routledge, 151-158.

Nieveen, N. \& Folmer, E. 2013. Formative evaluation in educational design research. Teoksessa T. Plomp \& N. Nieveen (toim.) Educational design research. Part A: An introduction. Enchede: SLO, Netherlands institute for curriculum development, 153-169.

Opetushallitus 2004. Perusopetuksen opetussuunnitelman perusteet 2004. Helsinki: Opetushallitus.

Pernaa, J. 2011. Kehittämistutkimus. Tieto- ja viestintätekniikkaa kemian opetukseen. Kemian opettajankoulutuksen väitöskirjat. Helsinki: Helsingin yliopisto.

Puolimatka, T. 2002. Opetuksen teoria konstruktivismista realismiin. Helsinki: Tammi. 
Plomp, T. 2010. Educational Design Research: an Introduction. Teoksessa T. Plomp \& N. Nieveen (toim.) An Introduction to Educational Design Research. Enschede: NetzoDruk, 9-36.

Plomp, T. 2013. Educational design research: an introduction. Teoksessa T. Plomp \& N. Nieveen (toim.) Educational design research. Part A: An introduction. Enchede: SLO, Netherlands institute for curriculum development, 11-50.

Rocard, M., Csermely, P., Jorde, D., Lenzen, D., Walberg-Henriksson, H. \& Hemmo, V. 2007. Science education now: A renewed pedagogy for the future of Europe. European Commission. Luxembourg: Office for Official Publications of the European Communities. Saatavissa: http://ec.europa.eu/research/science-society/document_library/pdf_o6 / report-rocard-onscience-education_en.pdf.Luettu10.6.2010.

Reeves, T. 2006. Design research from a technology perspective. Teoksessa J.V. Akker, K. Gravemeijer, S. McKenney \& N. Nieveen (toim.) Educational design research. New York: Routledge, 52-66.

Sandholtz, J. H. 2002. Inservice trainings or professional development: Contrasting opportunities in a school/university partnership. Teaching and Teacher Education 18 (7), 815-830.

Schreiner, C. \& Sjöberg, S. 2004. Sowing the seeds of ROSE. Background, rationale, questionnaire, development and dta collection for ROSE (The Relevance of Science Education) - a comparative study of students' views of science education. Acta Didactica, 4. Oslo: Universitetet i Oslo. Department of teacher education. Saatavissa: https://www.uv.uio.no/ils/english/research/projects/rose/actadidactica.pdf . Luettu 22.11.2014.

Tytler, R., Osborne, J., Williams, G., Tytler, K. \& Cripps Clark, J. 20o8. Opening up pathways: engagement in STEM across the primary-secondary school transition. Canberra: Australian Department of Education, Employment and Workplace Relations.

Wang, F. \& Hannafin, M. 2005. Design-Based Research and Technology-Enhanced Learning Environments. Educational Technology Research and Development 53 (4), 5-23.

Whitenack, D.A. \& Swanson, P. E. 2013. The Transformative Potential of Boundary Spanners: A Narrative Inquiry Into Preservice Teacher Education and Professional Development in an NCLBImpacted Context. Education Policy Analysis Archives 21 (57).

Wilson, N. S. 2008. Teachers expanding pedagogical content knowledge: learning about formative assessment together. Journal of In-service Education 34 (3), 283-298.

Zeichner, K. 2010. Rethinking the connections between campus courses and field experiences in college-and university-based teacher education. Journal of Teacher Education 61(1-2), 89-99.

Yin, R.K. 2003. Case study research: design and methods. 3. p. Newbury Park: SAGE.

\section{Liite 1}

Kolmannen aallon 2. syklin aloituskirje ja alkukyselylomake

LAIKO12 FyKe keväällä 2012 Nimi:

Maija Rukajärvi-Saarela ja Margetta Sarkkinen

Ympäristö- ja luonnontieto tutkimalla oppien ja opettaen

Fysiikka/Kemia

Jotta me kouluttajat yhdessä teidän koulutukseen tulevien opiskelijoiden kanssa voisimme saada aikaan mahdollisimman monipuolisen ja oikeaan osuvan fysiikka/kemian kurssin, odotammekin, että käytät muutaman hetken aikaasi ja mietit, mitkä ovat sinun tavoitteesi FyKe - kurssille sekä kerrot mielellään ainakin seuraavista asioi 
Taustatietoja omasta kemian ja fysiikan opiskelustasi ja opettamisestasi:

1.a Milloin viimeksi olet itse opiskellut kemiaa ja millainen muistikuva sen opiskelusta sinulle on jäänyt?

b Mitkä asiat vaikuttavat muistikuvaan päällimmäisinä?

c Millaisen tietopohjan kemiasta koet omaavasi tällä hetkellä?

d Oletko opettanut kemiaa ja jos kyllä, niin kenelle ja milloin? Millaiselta kemian opettaminen tuntui?

2.a Milloin viimeksi olet itse opiskellut fysiikkaa ja millainen muistikuva sen opiskelusta sinulle on jäänyt?

b Mitkä asiat vaikuttavat muistikuvaan päällimmäisinä?

c Millaisen tietopohjan fysiikasta koet omaavasi tällä hetkellä?

d Oletko opettanut kemiaa ja jos kyllä, niin kenelle ja milloin? Millaiselta fysiikan opettaminen tuntui?

Tutkimalla (tutkiva) oppiminen ja opettaminen

3.a Mitä tutkiva (tutkimalla) oppiminen ja opettaminen omasta mielestäsi tarkoittaa?

b Onko sinulla omakohtaisia kokemuksia joko tutkimalla opiskelusta tai opettamisesta? Jos kyllä, niin kerro esimerkki

Motivaatio ja innostuneisuus:

4.a Mitä keinoja sinä käytät saadaksesi opiskelun innostavaksi ja oppilaat motivoituneiksi?

b Miksi juuri nämä keinot ovat hyviä?

\section{Opiskeluympäristö:}

5. a Mikä on käsityksesi ja kokemuksesi alakoulujen varustelutasosta (tilat, välineet, aineet, opetusmateriaalit...) ajatellen kemian ja fysiikan opiskelua?

b Minkälaiset opetustilat mielestäsi parhaiten palvelisivat tutkimalla oppimista?

\section{Liite 2}

\section{Kolmannen aallon 2. syklin koulutuksen arviointilomake}

LAIKO12 FyKe keväällä 2012 Nimi:

Maija Rukajärvi-Saarela ja Margetta Sarkkinen

Mainitse muutama tehdyistä töistä, joita aiot käyttää työssäsi opettajana.

Miten luokassasi saat kemian/fysiikan opiskelusta innostavan ja motivoidun? 
Kerro omista kokemuksista, mitä tutkimalla oppiminen tarkoittaa oppijan näkökulmasta? Millaisia uusia näkökulmia sinulle avautui ke/fy -kurssin aikana?

Kirjaa joitakin omakohtaisia havaintoja toimimisestasi tutkimuksellisen opiskelun ohjaajana FyKe -kurssin aikana.

Helmiä oppimispäiväkirjasi käytöstä kasvussa kohti tutkivaa opettajuutta.

Palautetta 12 tunnin fyke -kontaktiopetuksesta. Ruusuja ja risuja!

\section{Liite 3}

Neljä näkökulmaa reflektoivan prosessipäiväkirjan kirjoittamisessa

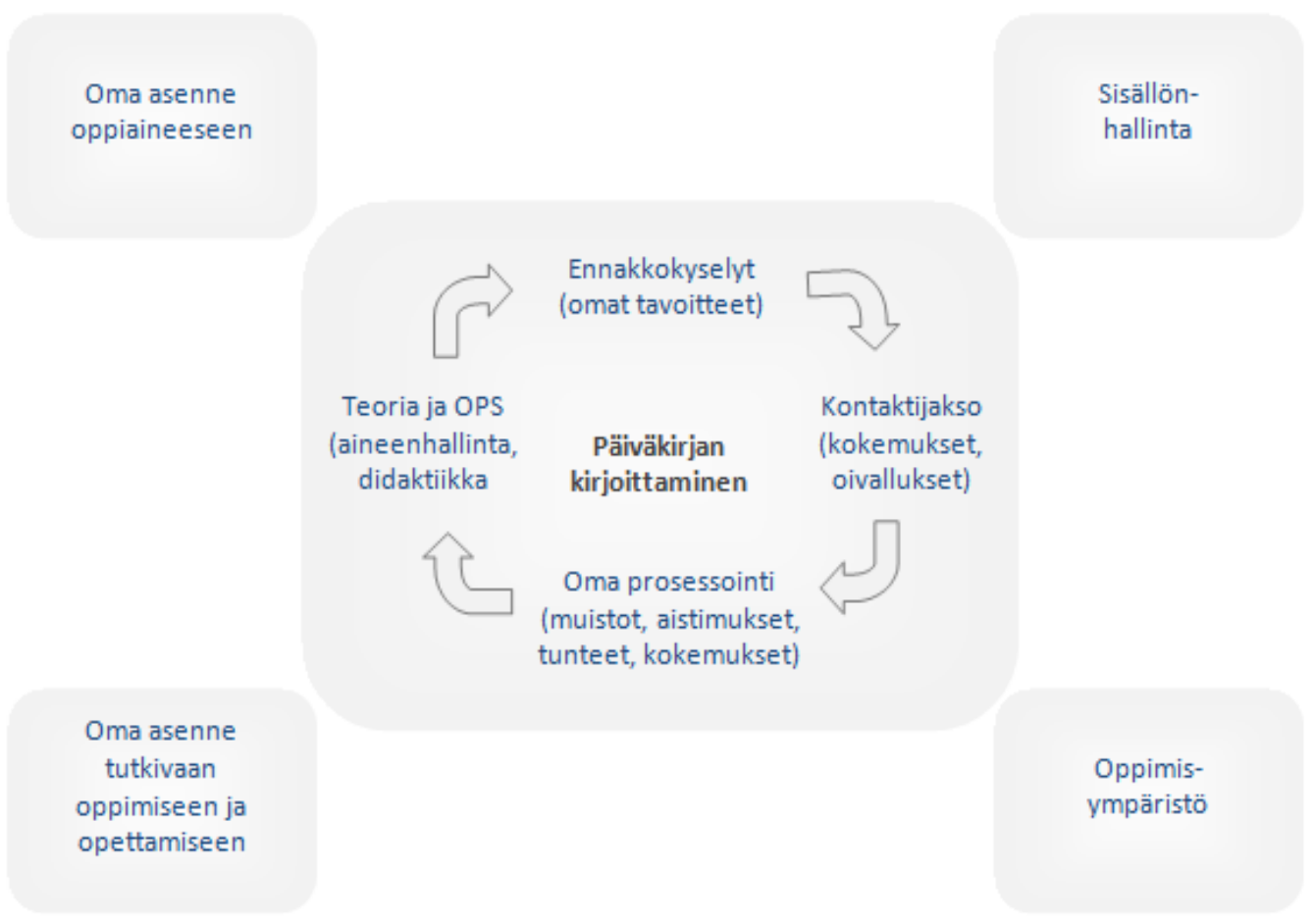

